\title{
Questões da filosofia (medieval) no teatro de Gil Vicente
}

\author{
Victor André Pinheiro Cantuário ${ }^{1}$
}

http://lattes.cnpq.br/5400803841633748

Enviado em: 30/09/2018

Aceito em: 12/03/2019

\begin{abstract}
RESUMO: O teatro vicentino, cuja força de expressão e originalidade impressionam a ponto de parte da crítica literária reconhecê-lo como iniciador do segmento em Portugal, surge em um contexto histórico-social, a Europa do século XVI - o quinhentismo português, no qual a presença da filosofia medieval ainda é persistente. Essa filosofia, em nada homogênea e dedicada, fundamentalmente, à discussão da questão do ser, a partir da qual avança a metafísica ocidental, desdobrandose na querela dos universais, entre outras, possivelmente, deixou rastros no teatro do dramaturgo português, constituindo-se a busca desses traços, desses vestígios em sua produção literária o objetivo deste escrito. A fim de se alcançar dito propósito, o artigo se debruça em referências que, primeiramente, apresentam o corpo histórico e as questões mais recorrentes da filosofia do medievo, assim como suas vertentes, sublinhando-se a grega, a islâmica, a judaica e a latina. Isto é cumprido por Corbin (1986), Nasr (2006), Gilson (2001), Libera (2011), Marenbon (2012), por exemplo. O segundo momento compõe-se de referências que investigam a obra de Gil Vicente em seus variados aspectos como a linguagem, a sociedade, a política, os costumes etc.; nesse momento tomam parte Teyssier (1982), Moura (1987), Moisés (2008), Saraiva e Lopes (2010); para finalmente compor-se a cena dedicada ao trabalho de rastreio esboçado no objetivo mencionado, seção na qual se há de fazer uso das Obras de Gil Vicente (1965), publicadas pela reconhecida editora portuguesa Lello \& Irmão. Crê-se que o resultado desta investigação é o cumprimento de suas aspirações apropriadamente ao se ter localizado nas peças vicentinas selecionadas temas e questões tratados pelos filósofos medievais, assentadas na dualidade platonismo/aristotelismo, traduzindo-se em mais que preocupações de momento, em uma visão de mundo e de homem, a qual certamente se estendeu às artes, em geral, e à literatura, em particular, atingindo profundamente o dramaturgo lusitano.
\end{abstract}

Palavras-Chave: Teatro português quinhentista; Filosofia medieval; Metafísica; Existência.

ABSTRACT: Gil Vicente's theater, whose power of expression and originality left so many impressed, making part of the literary criticism to recognize him as the initiator of this kind of art in Portugal, has appeared in a social-historical context, Europe of the 16th century - the Portuguese quinhentismo, in which the presence of the medieval philosophy is still persistent. This philosophy, in nothing homogeneous and dedicated, fundamentally, to the discussion of the question of being, from which the western metaphysics advances, unfolding in the dispute of the universal ones, between others, possibly, left traces in the theater of the Portuguese playwright, and the objective of this article lies in exactly searching for these aspects, these traces in his literary production. In order to achieve this purpose, the article will make usage of references that, firstly, present the historical body and the most frequent questions of the Middle Ages philosophy, as well as its trends, the Greek, the Islamic, the Jewish and the Latin one. This is pointed out by Corbin (1986), Nasr

\footnotetext{
${ }^{1}$ Doutorando em Estudos Literários pela Universidade Estadual Paulista (UNESP). Professor efetivo da Universidade Federal do Amapá em Filosofia da Educação. Atua em pesquisas discutindo ética, com ênfase na contemporaneidade; estética e suas relações com o consumo; filosofia e literatura.

E-mail: loquorlatinae@hotmail.com
} 
(2006), Gilson (2001), Libera (2011), Marenbon (2012), for example. The second moment is composed of references that investigate the work of Gil Vicente in many ways as the language, the society, the politics, the customs etc.; in this moment will contribute Teyssier (1982), Moura (1987), Moisés (2008), Saraiva e Lopes (2010); at last the final moment will be dedicated to the analysis of the work by searching for the philosophical traces mentioned above, section in which it will be used the Obras de Gil Vicente (1965), edited by the renowned Portuguese publisher Lello \& Irmão. The writer believes that the result of this investigation is the fulfillment of his aspirations appropriately because have been located in the plays of Gil Vicente selected the subjects and questions discussed by the medieval philosophers, established in the Platonism-Aristotelianism dualism, being translated in more than concerns of those times, but in a vision of world and man, which certainly reach to the arts, in general, and to the literature, in particular, precisely achieving the Portuguese playwright.

Keywords: 16th century Portuguese theater; Medieval philosophy; Metaphysics; Existence.

\section{Introdução}

Há disponível atualmente considerável produção acadêmica a respeito da obra de Gil Vicente, partindo de uma porção desta (das comédias, das farsas, das moralidades) ${ }^{2}$ ou, por vezes, concentrando esforços de análise na(s) linguagem(ns) do autor (TRIGO, 1983); em algumas relações que são possíveis de serem estabelecidas, como entre o seu teatro e a visão religiosa da época (COELHO, 2017); a cena política ou a vida na corte portuguesa quinhentista (FARIA, 2005; MUNIZ, 2005); e ainda o vestuário característico deste século, representado nas encenações dos autos, deixando pistas de costumes ou formas de comportamento típicos do tempo em que viveu o dramaturgo (BOMFIM, 2008).

A respeito da associação de sua produção literária com a filosofia, certas afirmações têm se limitado a considerar os traços de platonismo e platonismo-agostiniano ou aristotelismo (ARAGÃO, 2002; EYLER, 2014) encontrados em suas peças, entretanto, outras correntes filosóficas estiveram em vigor, floresceram ou decaíram no período em que viveu o dramaturgo português, provavelmente da segunda metade do século XV à primeira do século XVI, contando-se que além da presença da filosofia de vertente romana, da qual a cristã se origina no século II EC (OSBORN, 1981), aponta-se a grega, que chega à Europa cristã por meio dos comentários, interpretações e traduções feitos tanto pelos autores latinos $^{3}$ quanto pelo importante trabalho dos islâmicos 4 (GILSON, 2001), e a filosofia judaica, que desponta neste momento fortemente influenciada pela anterior, ambas tendo suas origens datadas no século IX EC (CORBIN, 1986; GUTTMANN, 1966), constituindo-se o conjunto do que se denomina filosofia medieval, que em nada é homogênea, mas resultado do contato e da apropriação das quatro tradições mencionadas.

Da observação feita segue-se que este artigo objetiva situar o teatro de Gil Vicente no contexto filosófico medieval, propondo-se a expor influências outras que o platonismo e o

\footnotetext{
2 Paul Teyssier (1982) comenta não haver consenso quanto à divisão da obra vicentina, contudo para este a querela é resolvida pelo próprio autor ao distinguir as três categorias acima, fato descrito em carta a D. João III.

${ }^{3}$ Etienne Gilson (2001) destaca que a literatura cristã latina nascente em Roma teve como sua primeira língua de expressão o grego, impondo-se o latim somente no século III EC.

${ }^{4}$ Segue-se explicação do filósofo e orientalista francês Henry Corbin que defende ser mais apropriado chamar essa vertente de pensamento de "filosofia islâmica" porque o islamismo é muito maior como fenômeno cultural e religioso que o designativo étnico árabe, portanto, incluindo em si também o que ao longo da Idade Média e depois tornouse comum reconhecer como "filosofia árabe", ainda que outros, como Gilson utilizem "islâmica" e "árabe" para se referir a essa filosofia.
} 
aristotelismo. Para isso, primeiro será constituído panorama do pensamento filosófico desse momento para, em seguida, buscarem-se nos autos do período que vai de 1502 a 1536, motivos, ou seja, temáticas que remetam às perspectivas filosóficas com as quais provavelmente o autor entrou em contato, respirando o ar de seu tempo, pois que se fala de personagem histórica educada à maneira de seus contemporâneos, ainda que não erudito, mas homem de letras, a despeito de suas origens humildes.

\section{A filosofia do medievo é a busca pelos universais?}

A filosofia medieval é a conjunção de quatro ${ }^{5}$ fortes tradições que estarão em contato e irão influenciar a constituição do pensamento desse período de maneira nada homogênea. Eis razão suficiente para não se apresentar delimitação cronológica dessa filosofia, a não ser para fins situacionais, como o faz Alain de Libera, pois esbarra em culturas, portanto, visões de mundo distintas.

De acordo com o filósofo medievalista francês, a Idade Média, como costumeiramente se divulga, identificando seu início com a derrocada do Império Romano do Ocidente, no ano de 476, e seu término, em 1453 EC, na tomada de Constantinopla pelo Império Turco, simplesmente não existe, e essa defesa de uma não existência, aparentando ser mais conceitual que real, refere-se à pluralidade cultural aí vigente, isto é, conhecendo-se a conquista da Península Ibérica pelos muçulmanos, no século VIII EC, II da Hégira, ano 4.472 do calendário judaico, conquista que perdurou por quase 800 anos, gerando um ambiente de troca cultural, ainda que forçada, definir seus limites a partir do olhar da cristandade latina é, em si, defender um posicionamento e fechar a questão em apenas uma raiz de pensamento (LIBERA, 2011), o que soa agressivo, visto a intenção ser exatamente a contrária: construir percepção de como, em que nível e através de quais referenciais as quatro tradições estiveram irremediavelmente unidas.

Essa conjunção de tradições e, por consequência, perspectivas encontra eco em John Marenbon (2012), para quem as quatro vertentes se dispõem de maneira a ser perceptível a contribuição de cada uma para a formação do pensamento medieval: primeiro, a grega, que servirá de base para o desenvolvimento das demais; em seguida, a islâmica, cujas traduções contribuirão significativamente para o conhecimento da anterior; em sua trilha, a judaica, que além de se relacionar intimamente com a islâmica dará nova luz a questões da filosofia grega antiga e, por fim, a latina que já vinha se desenvolvendo dos últimos séculos antes aos primeiros da EC. Note-se que essa disposição ressalta não a ordem de aparecimento ou a importância de cada tradição, portanto, não é valorativa, mas, conforme dito acima, vê a maneira como se relacionam para dar origem à filosofia da Idade Média.

Quanto aos temas 6 , uma das bases do pensamento filosófico medieval é a investigação

\footnotetext{
${ }^{5}$ Não se desconhece, dado o referencial utilizado, o papel desempenhado pela tradição siríaca nas traduções das obras dos filósofos gregos, principalmente Aristóteles, nos séculos IV e V EC, entretanto, não se inclui essa vertente por haver se restringido ao Oriente, mas sua importância não é negada. A esse respeito, Gilson (2001, p. 424) esclarece: "as escolas siríacas foram as intermediárias pelas quais o pensamento grego chegou aos árabes, enquanto não chegava o momento em que devia passar dos árabes aos judeus e aos filósofos do Ocidente cristão."

${ }^{6}$ Cf. BOSLEY, Richard N; TWEEDALE, Martin M (Eds.). Basic issues in medieval philosophy. 2nd. ed. Toronto: Broadview Press, 2006. O livro está organizado em tópicos, nos quais constam os filósofos medievais que discutiram de maneira mais significativa os problemas característicos de seu tempo. Alguns temas de destaque tratados na obra são: "necessidade, contingência e liberdade"; "determinismo, livre-arbítrio e presciência divina"; "virtude, razão, corpo, alma e intelecto", além daqueles apresentados no corpo do texto.
} 
e o debate dos então denominados "universais", que de acordo com as compreensões da época constituiu-se em problema desde a Isagoge do filósofo neoplatônico Porfírio (século IV), tomando forma na interpretação de Boécio (século VI), e estendendo-se até a quase solução de Aberlado (século XII), porque além de alimentar o imaginário do homem do medievo, discutia questão-problema iniciada por Platão em seu Parmênides e duramente criticada por Aristóteles, expressa em três pontos. Primeiramente, são os universais realidade ou se limitam a conceitos mentais, a pensamento? O segundo ponto questiona: se são reais, isto é, se existem, possuem materialidade ou não? E finalmente, estão nas coisas deste mundo, nos seres, nos objetos ou não? As soluções ou tentativas de explicação, apoiar-se-ão ora no primeiro, ora no segundo filósofo, desdobrando-se em três correntes que se afastam consoante a resposta que darão: o realismo, posição mais antiga que remonta aos filósofos gregos, cuja apreensão do problema defendia que nome e coisa se correspondem; o nominalismo, por sua vez, advogava ser o nome somente conceito utilizado para identificar a coisa; por fim, o conceitualismo dava entendimento de tudo se resumir a conceitos mentais (MARENBON, 2012; GILSON, 2001; LIBERA, 1996).

Outras investigações despontaram no seio da filosofia medieval, como as teses que deram conta de provar a existência de Deus, desde o princípio sensível de João Damasceno (século VIII), passando pelo conhecido argumento ontológico de Anselmo de Cantuária (século XI), tendo como ponto de distinção as cinco vias de Tomás de Aquino (século XIII). Evidentemente, a filosofia do medievo não se resumiu a esses tópicos, principalmente tendo-se em vista a entrada em cena, no século do "Doutor angélico", das filosofias islâmica e judaica, as quais estiveram diretamente ligadas mais ao pensamento grego, do qual se apropriam integralmente, que do latino.

Para se tecer quadro de observação dos problemas específicos das vertentes islâmica e judaica, por ordem de aparecimento e produção, os grandes nomes de destaque da falsafa 7 são: Alkindi (século IX), Alfarabi e Avicena (século X), Averróis (século XII). Os motivos mais debatidos nessa primeira fase, de base aristotélica, discutem a superioridade do intelecto sobre a alma; a tentativa de conciliar os pensamentos daquele com o platônico; ademais, "os filósofos árabes defrontaram-se, antes dos cristãos, com o problema de conciliar uma concepção grega do ser e do mundo com a noção bíblica de criação" (GILSON, 2001, p. 427).

Em desenvolvimento dos motivos postos e, justamente, como parte deles, é possível atestar-se que o centro do pensamento filosófico islâmico, ou seja, o tema sobre o qual essa filosofia se assenta é "o ser e a existência", de tal maneira que o pensador iraniano Seyyed Hossein Nasr (2006), dissertando sobre a matéria, escreve ter havido período considerável de tempo, composto por onze séculos, no qual essa foi a preocupação maior dos filósofos islâmicos daquela época, atingindo profundamente as outras duas tradições com as quais o islamismo dividiu terreno, a cristã e a judaica.

Inegável que, em sendo uma filosofia delineada no seio e a partir da fé muçulmana, a

\footnotetext{
${ }^{7}$ A título de curiosidade, falsafa é a palavra em árabe para filosofia, ou, mais expressamente, o que nas línguas europeias se entende pelo termo filosofia, em árabe, relacionando-se às tradicionais fontes do islamismo, se entende por alfalsafah, porque filosofia é um termo que se utilizado para o pensamento islâmico, "estender-se-ia a muitas outras disciplinas islâmicas tradicionais como os comentários corânicos (tafsir e ta'wil), os princípios da religião (usul al-din), os princípios da jurisprudência (usul al-fiqh), o sufismo, as ciências naturais e as ciências da linguagem" (NASR, 2006, p. 13). Quer dizer, para o pensamento islâmico o domínio do filosófico é mais específico que para o pensamento europeu, consequentemente, ocidental. Isto significa que nem tudo identificado como filosófico é, de fato, filosofia no islamismo (CORBIN, 1986).
} 
falsafa dedicará bastante espaço para o desenvolvimento de uma mística e de uma meditação filosóficas marcadas em sua essência pelos ensinamentos corânicos e pela revelação profética, derivando para o que Corbin (1986) chama de "filosofia profética", mas ainda assim filosofia, portanto, nada do que se habituou na cristandade a expressar, quando são postas lado a lado filosofia e teologia, por meio da submissão da primeira à segunda, um tipo de "fillosofia serva da teologia". ${ }^{8}$ Em verdade, esse é um equívoco grave e persistente que demanda correção e com o qual nenhum dos estudiosos aqui citados, certamente, estaria de acordo.

Em certa medida, o "profetismo" como forma de reconhecimento da tradição islâmica também caracterizará a vertente judaica. Isto é afirmado pelo fato, já exposto, de que ambas as tradições, desde suas origens, estão entrelaçadas em suas culturas, na escolha de seus problemas e, em decorrência disso, nas razões de suas investigações, consistindo em um jeito de se filosofar agregando ideias estrangeiras e as conformando às perspectivas do judaísmo (GUTTMANN, 1966).

A filosofia do judaísmo é uma filosofia que se origina sob o signo da Diáspora: o segundo Templo de Jerusalém é saqueado e incendiado pelas legiões romanas lideradas por Tito, em 70 EC, este viria a se tornar imperador nove anos após o sítio, iniciando novo processo de dispersão que ganhou força com a derrota do levante judaico liderado por Bar Kokhba desta vez para o imperador Adriano, que a seguir os proíbe de adentrarem em Jerusalém, forçando-os a migrarem para terras próximas do Oriente Médio, do Norte da África ou para a Península Ibérica. Certamente, a dispersão de judeus é anterior à determinação de Adriano, mas aí ganha uma tonalidade outra. E a situação da migração não se dá de maneira homogênea, pois mesmo antes do sítio à Jerusalém os judeus já se faziam presentes na Europa (JOSPE, 2009; LIBERA, 2011).

De seu trajeto, incluindo migração do Oriente para o Ocidente e a chegada na Península Ibérica durante o que se convencionou em historiografia 9 , a partir do entendimento de recortes espaço-temporais, a chamar de alta Idade Média, alguns pontos do percurso da filosofia judaica, e das influências diretas que incidiram sobre esta se veem quando "passou pela Espanha em ritmo parecido com o de sua vizinha árabo-muçulmana” (LIBERA, 2011, p. 191); mas à diferença desta, a vertente judaica viu-se obrigada a enfrentar uma série de eventos com os quais convivera durante toda sua história por fazer parte da própria história do povo judeu: as perseguições religiosas, as intervenções em favor de conversões forçadas que, se recusadas, findavam em novos deslocamentos como resultado de expulsões.

Faz-se importante para percepção do percurso dessa vertente saber que do islamismo, “o pensamento judaico herdou o kalâm ${ }^{10}$ - houve um kalâm judaico; recebeu também corpus

\footnotetext{
${ }^{8}$ Duignan (2011) reconhece a figura do monge beneditino e reformador Petrus Damianus (século XI) como o primeiro a provavelmente ter pronunciado essa "infame" sentença. Libera (2001), ao seu turno, afirma ter sido antes o ambiente universitário, cujo sentido difere do de hoje, que o teológico o lugar de primeira difusão da ideia, pois naquele havia, de fato, certa "submissão", expressa na hierarquia e divisão das áreas de estudo. Nesse contexto, estaria a filosofia em posição inferior ao ensino de teologia, esta gozando de maior prestígio que aquela, pois o ensino filosófico estava contido na faculdade de Artes, a qual ao lado da Medicina, do Direito e da Teologia compunha a organização do saber europeu medieval entre os séculos XI a XIII, quando são fundadas as primeiras Universidades.

${ }^{9}$ Cf. BARROS, João D'Assunção. Os usos da temporalidade na escrita da história. Saeculum - Revista de História [13]; João Pessoa, jul./dez. 2005. p. 144-155.

${ }^{10}$ Kalâm é um termo usual da filosofia religiosa do islamismo medieval, em grande parte racionalista, às vezes apologético (ou polêmico). O significado literal da palavra árabe é fala, discurso, coisas ditas, discussão. No contexto do pensamento religioso, parece que em torno do oitavo século o kalâm adquire o sentido de método de discutir questões relacionadas a doutrinas religiosas ou político-religiosas, solucionando-as mais através do uso de argumento racionalista que da autoridade da tradição" (BEN-SHAMMAI, 1997, p. 91). Comente-se que essa característica do
} 
filosófico que cresceu com os anos - os filósofos islâmicos serviram-lhe de constante fonte de inspiração, desde Alfarabi até Averróis" (Idem, p. 192, itálicos do autor); e nos primórdios da filosofia medieval do judaísmo não se falava ou se escrevia em hebraico, a língua dos primeiros filósofos judeus do medievo foi o árabe. "A adoção da língua árabe pelos judeus, no final do século IX, do Iraque até a Espanha (o hebraico e o aramaico restringiam-se ao uso erudito), foi um fator poderoso de intercâmbio cultural com o mundo muçulmano" (Idem, ibidem).

Deve-se notar que não apenas a cultura e a herança filosófica islâmicas se fizeram presentes na filosofia judaica; o princípio deste pensar está no período hoje denominado helenístico (século IV AEC ao I EC) e encontra primeiro expoente na figura de Fílon de Alexandria (século I EC), momento em que se deu contato inicial entre as duas matrizes de pensamento, a grega e a judaica, contudo, não originando um pensar filosófico propriamente judaico e uma justificativa estaria na ideia de que Fílon se dedicou mais à revisão ${ }^{11} \mathrm{e}$ ao comentário que à proposição de problemas ou caminho propriamente entendidos como filosóficos, abraçando como tarefa a tentativa de reconciliar as duas tradições com as quais conviveu diretamente; acrescente-se que o filósofo judeu-helenístico não encontrou muita recepção na cultura judaica, tendo despertado mais o interesse dos pensadores cristãos.

Avançando no tempo e atingindo o medievo, pelas razões já expressas, a anterioridade da falsafa preparou terreno para o surgimento de um pensamento filosófico no seio do judaísmo que se irá configurar em algumas vozes de destaque.

Os motivo e os problemas da filosofia judaica medieval são aqueles levantados pelos neoplatônicos e pelos islâmicos; por aqueles porque se constituíram cedo em escola de pensamento, indo do século III ao VII EC, para dar continuidade ao e dispor interpretações do pensamento de Platão; por estes "se explica não só pelo contato íntimo e prolongado das civilizações judaicas e árabes, mas também - e, talvez, sobretudo - por seu estreito parentesco de raça e a semelhança de seus gênios" (GILSON, 2001, p. 454). Isto é, o pensamento filosófico judaico se ocupou da tentativa de reconciliar ciência e tradição religiosa, demonstrando posição a respeito da tentativa de provar a existência de Deus, com Saadia (século X), e o hilomorfismo ${ }^{12}$, neste tópico, defendido por Gabirol (século XI), pretendendo que todas as substâncias existentes, corpóreas ou espirituais, excluindo-se Deus dessa composição, constituem-se de matéria e forma. Seguindo de perto os iniciadores do judaísmo filosófico dessa fase, a figura de Moisés Maimônides (século XII) representa ponto alto da vertente, mas a que isso se deve?

Maimônides foi severo crítico dos filósofos anteriores a si, apontando as fragilidades de suas proposições ou o excesso de revisionismo de seus escritos, os quais, desse ponto de vista, pouco acrescentaram à filosofia do judaísmo; por isso, decidido a confrontá-los e expor definitiva conciliação da filosofia grega com a religião revelada, escreveu obra de referência para o pensar do medievo, O guia para o perplexo (c. 1190), que atraiu a atenção de autores da cristandade, tornando-a leitura obrigatória.

Maimônides pode ser visto buscando pontos de apoio para sua conciliação de fé e

kalâm de ir do religioso e filosófico ao político apoia-se na compreensão, a partir de sua constituição religiosa, da sociedade islâmica, a qual não dissocia os aspectos da vida social daqueles da profissão de fé, todas as dimensões se inter-relacionam.

11 Aqui os termos "revisão", "revisionismo" são entendidos negativamente, limitando-se à leitura e ao comentário de obra, não representando avanço em nenhum sentido.

12 Termo proveniente do vocabulário filosófico, língua grega, resultando da aglutinação de bulê (matéria) e morphê (forma). Vide: AINSWORTH, Thomas. Form vs. matter. The Stanford Encyclopedia of Philosophy, 2016. Disponível em: < https://plato.stanford.edu/archives/spr2016/entries/form-matter/>. Acessado em: 20 ago. 2018.

https://periodicos.unifap.br/index.php/letras Macapá, v. 9, n. 1, $1^{0}$ sem., 2019 
razão ao partir da ideia de que estas não se podem dissociar simplesmente por serem provenientes de Deus, portanto, qualquer problema de conciliação resulta, antes de mais nada, de problema de interpretação de uma (fé/religião revelado) ou de outra (razão/filosofia). Outrossim, Maimônides atesta haver, sem dúvida, um elo de ligação relacionando o evento iniciador das religiões monoteístas, a criação ou gênese, com princípios advindos da filosofia para explicar as origens de tudo, e finaliza suas considerações demonstrando "que os argumentos aristotélicos a respeito de um mundo eterno não são conclusivos porque ignoram a onipresença de Deus, o qual pode criar um mundo com duração finita ou infinita [de acordo com sua vontade]" (DUIGNAN, 2011, p. 87). Agindo desta forma, Maimônides alcança êxito que há de perdurar no repertório não somente da filosofia do judaísmo como no corpo maior da filosofia da Idade Média, impressionando historiadores da filosofia judaica que irão reconhecer aí uma "síntese genuína" (GUTTMANN, 1966, p. 172).

Um dos últimos assuntos ao qual se precisa fazer menção entre os temas da filosofia medieval é à moral do homem desse tempo, pois vendo-se que havia forte embasamento religioso permeando as discussões da época, no tratamento dos fatos morais não poderia ser diferente.

Julius Guttmann (1966), Raphael Jospe (2009) e Michael Dougherty (2011) escrevem da moral medieval que deve preencher o homem de disposição para opor-se às paixões do mundo e evitar os apetites do corpo, posto que o maior objetivo de uma vida moral, nessa perspectiva, é a ascensão da alma, portanto, a moral do medievo é vertical, ascética, baseada no abandono e no desapego das coisas deste mundo, em cumprimento da mensagem de Jesus nos Evangelhos, do buscar o reino dos céus, para isto deve-se estar constantemente em busca da verdade (dimensão reflexiva), e agir corretamente (dimensão prática), uma conjunção de duas dimensões para cada vez mais o homem se fazer semelhante e estar mais próximo de Deus, orientando-se pela máxima “dever não é poder", na qual se consolida a proibição como expressão da vontade divina.

Finalmente, espaço para curto comentário sobre tema extremamente representativo da cultura medieval, mas cuja visão tem sido negligenciada, como a própria ideia de que na Idade Média se produziram discussões morais genuínas: dos temas morais são extraídos os entendimentos da relação bem e mal. Se agir moralmente é portar-se de acordo com a vontade divina e, portanto, não a contrariar, o mal na Idade Média é resultado da desobediência humana, é resultado da violação de um estatuto que em tese guia a existência de cada um, contudo, quando praticá-lo, desobedecer, é inevitável, põe-se em cena um dilema moral materializado no princípio o "menor de dois males" - cujas raízes são encontradas em Platão e Aristóteles -, isto é, diante da impossibilidade de transgredir regras morais e da escolha entre duas ações sendo ambas, dadas as suas naturezas e finalidades, más, o agente moral deve optar pela que cause o menor dano possível, quer dizer, pela menos imoral. E este é um tema que, de acordo com Dougherty (2011), ocupou os filósofos medievais, havendo, como não poderia deixar de ser, defensores, apresentando sugestões ou conselhos, e contrários a esse princípio, descartando essa possibilidade completamente.

Percebe-se, das tradições de pensamento apresentadas, tendo-se em conta os delineamentos de suas características essenciais e a exposição de seus problemas fundamentais, que contribuíram para a constituição de prolífico cenário no qual a filosofia desenvolveuse grandemente, por isso, contrariando olhar comum e desavisado que a enxerga como sendo infértil e excessivamente revisionista, olhar que indevidamente paira nesse capítulo de sua história. 
De fato, a filosofia medieval é costumeiramente mal compreendida e mal interpretada, pesando sobre ela juízos grosseiros que a determinam como mera extensão do pensamento grego e reunião de autores e obras dedicados somente à interpretação e ao comentário e isto é tudo de que ela em nenhum sentido pode ser acusada.

\section{O teatro vicentino é retrato da sociedade portuguesa medieval?}

O teatro português, tem parcela da crítica literária admitido, inicia com Gil Vicente (MOURA, 1987), entretanto, há compreensão outra de existir cena teatral na cultura portuguesa antes que o poeta da corte ${ }^{13}$ tivesse sua primeira obra encenada em junho de 1502 (GIGANTES, 1972), tendo, portanto, ele aprimorado formas já existentes, elevando-as ao nível de obras literárias com distinto valor e não apenas releituras semelhantes ao que se pode observar no Cancioneiro Geral reunido por Garcia de Resende (SARAIVA e LOPES, 2010). Para além da defesa ou não de tal pioneirismo, a sua contribuição foi fundamental ao reconhecimento da tradição literária aqui referenciada cujo nascimento efetivo se dá no medievo (MOISÉS, 2008, PICCHIO, 1969).

Algumas observações gozam de pertinência para que se passe à tentativa de situar no teatro vicentino demandas da filosofia medieval. A primeira delas refere-se à natureza deste, isto é, apesar de entendimento a respeito informar que o teatro vicentino o é de corte (TEYSSIER, 1982; MUNIZ, 2005; EYLER, 2014), sobressai-se forte apelo popular no de Gil Vicente, possivelmente resultado das origens humildes do teatrólogo português, mas também de suas anotações da vida cotidiana citadina, e do que acontecia no paço; isto finda por estender-se à galeria de seus personagens: os anjos, arcanjos e serafins, personagens bíblicos, personagens históricos, os santos e demônios, o papa, o ermitão, o frade, o clérigo, a feiticeira, o judeu, o cigano, o mouro, o francês, o castelhano, a portuguesa, o rei e seu séquito, são os tipos religiosos, étnicos e da nobreza que transitaram ou constituíram a sociedade portuguesa quinhentista; a igreja, as estações, os deuses greco-romanos, a fama, a fé, a fortaleza, a morte, as fadas, o mundo, o tempo, a verdade são representações do imaginário desses tempos; o escudeiro, o cavaleiro, o pastor, o vaqueiro, o sapateiro, o procurador, o fofoqueiro (onzeneiro), o parvo, as regateiras, o lavrador, as alcoviteiras, as moças, os meninos, caricaturados ou não como tipos corriqueiros circulando no ambiente do poeta, um ambiente farto de todos os tipos e de variado fluxo de pessoas e línguas, algo a permitir comentário de segunda observação importante.

O visível bilinguismo da corte - castelhano, em razão de as esposas dos monarcas compartilharem essa origem no século XVI; e português, por ser a língua do reino - se faz sentir na própria produção vicentina: das 44 peças escritas e registradas, 11 o foram em castelhano, 16 em português e 17 são bilíngues (MOURA, 1987).

Esse bilinguismo aponta, inevitavelmente, para a inserção de elementos de ambas as culturas no corpo da obra do dramaturgo português, e, afirme-se, persiste nesta traços tanto da presença e herança islâmicas, cujo domínio se estendeu sobre a Península Ibérica por quase 800 anos, quanto da cultura judaica, em função de seu estabelecimento nesse mesmo terreno graças à relativa liberdade de que puderam gozar até nova perseguição iniciada com Reconquista de 1492.

O terceiro aspecto que se destaca é a própria evolução do teatro vicentino. Em suas

\footnotetext{
13 Teysssier (1982), Muniz (2005) e Eyler (2014) informam ser essa a função oficial desempenhada pelo dramaturgo, sob dois regentes, D. Manuel e D. João III, comentando que a concepção de seu teatro, bem como os objetivos aos quais servia caracterizam-no como sendo teatro de corte.
}

https://periodicos.unifap.br/index.php/letras Macapá, v. 9, n. 1, $1^{0}$ sem., 2019 
considerações a respeito, Massaud Moisés (2008) menciona que é possível se distinguir três fases no teatro vicentino: a primeira sob a influência espanhola de Juan del Encima, de 1502 a 1514, portanto, um teatro em formação - incluindo desde o Auto da visitação, daquele, até $A$ comédia do viúvo, datando deste último ano; a segunda de 1515 a 1527, o ápice da carreira do autor, abrangendo desde o Auto da barca do inferno (1517) ao Auto da feira; a terceira de 1528 até sua morte, incluindo do Triunfo do inferno (1529) à última produção conhecida Floresta de enganos (1536), quando Gil Vicente apura a linguagem de seu teatro, graças às influências do classicismo renascentista.

Pelos seus temas, pode-se classificá-lo em tradicional, quando sobressaem-se formas já dominantes no teatro medieval como a liturgia; e de atualidade, quando passa ao registro fiel da sociedade de seu tempo. A partir desses elementos, pode-se deduzir que o maior mérito do teatrólogo lusitano está no fato de ser poeta com fortes acentos de "poeta dramático (...) o seu valor manifesta-se numa fluência e elasticidade expressivas que abarcam todos os matizes, líricos, satíricos, mitológicos, alegóricos, religiosos, sem perder a sua peculiar fisionomia" (Idem, p. 57).

Das fontes que serviram de inspiração ao teatro de Gil Vicente, saltam as que provêm da tradição oral, dos romances de cavalaria, das alegorias, como o exemplo citado por Saraiva e Lopes (2010), nas quais se assentam as Barcas, inscrevendo-se na tradição que remonta ao escritor grego Luciano de Samósata, do serviço religioso, como os sermões, as ladainhas (litanias) etc. Perceptível é a variedade de gêneros literários que irão convergir para a composição de um rico teatro sem precedentes e do qual deriva escola iniciada ainda no tempo vivente do dramaturgo português (MOISÉS, 2008).

Ao se elencarem os assuntos mais recorrentes nas peças vicentinas, pensa-se em retirálos não do teatro em si, mas do contexto histórico-social que lhes serviu de pano de fundo, e comprova-se que Gil Vicente falou de tudo que havia e acontecia no seu tempo, vero cronista revestido em dramaturgo; "ocupam-no muitas vezes a apologética religiosa, a noção do bem e do mal, a do livre arbítrio, o sacrifício pela Fé", que são em si matérias extraídas da filosofia e da teologia do momento; ademais, "a vida descontentadiça e maldizente, a leviandade e a hipocrisia das mulheres, o gosto da ostentação e das aparências, o drama do querer e do não poder, as práticas de feitiçaria, os amores romanescos, venais, proibidos ou senis", problemas que tocavam nas questões morais defendidas ou atacadas no medievo; e, por fim, "as intrigas paçãs, as presunções e pretensões da medicina coeva, os problemas da vida e da morte e as preocupações do além, os dissídios conjugais, o espírito patriótico, a ufania dos descobrimento e das recentes conquistas no ultramar", ecos da maneira como o homem português via a si mesmo nesse mundo que se descortinava trazendo novos desafios a serem vencidos (MOURA, 1987, p. 28).

Desses motivos é que se pode ter uma ideia de quão agudo foi o olhar de Gil Vicente, não dispensando absolutamente nada e permitindo que tudo lhe dissesse respeito figurando nas encenações realizadas no paço, com a nobreza assistindo atenta às representações de seus vícios e debilidades, de suas crenças, superstições e perspectivas de mundo, escondidas ou não nas falas das personagens, as quais, seguramente, atestavam os posicionamentos do próprio dramaturgo.

Questionando-se suas influências literárias e fontes, seriam elas as de um homem erudito do medievo com conhecimentos profundos de latim e da cultura humanista? A resposta da crítica tem esbarrado em posicionamentos a favor e contrários, havendo defesa altiva destes últimos ao apoiarem-se na compreensão de que quando se passa à colheita do material linguístico, do vocabulário, das citações em língua latina e dos nomes que fazem 
referência ao mundo antigo, constata-se Gil Vicente deles ter lançado mão na medida em que se repetiam no uso comum e na cultura em que viveu, portanto, nada de louvável há nesse procedimento.

Sobre tal ponto, assevere-se que se Gil Vicente não pode ser tido como homem erudito, simplesmente porque seu latim estaria "incorreto", por outro lado não se devem diminuir seus méritos como autor (TRIGO, 1983). Certo que possuía noções de seu tempo e da cultura comum de então, dos rituais e dos procedimentos litúrgicos, deles tendo maior ciência que da literatura latina, por exemplo. "Vivia numa época e num meio em que, mesmo sem o querer, se respirava o latim no ar ambiente; e tinha, além disso, um conhecimento perfeito da língua castelhana, na qual escreveu cerca de um terço da sua obra" (TEYSSIER, 1982, p. 14), e todos esses aspectos precisam ser considerados não se devendo pender nem para o descrédito nem para a aceitação cordial, provavelmente, o recomendado seria andar pelo terreno que é Gil Vicente buscando o meio-termo como postura crítica, admirando-se seus acertos e reconhecendo-se suas fragilidades, o que obviamente qualquer autor possui.

Passando a outro aspecto, para chegar ao corpo de sua obra, é necessário antes ser dito que é produto de reunião organizada, principalmente, por filhos de seu segundo casamento, Luís, o editor, em cooperação com a irmã Paula Vicente, trabalho finalizado em 1562 sob o nome de Compilaçam de Todalas Obras de Gil Vicente. Aí novamente a crítica vicentina incide afirmando que se está lidando com esforço mal empreendido por ser trabalho mal feito, e algumas palavras em particular têm sido empregadas para dar juízo da compilação, entendendo a crítica tratar-se de obra "mutilada", "inautêntica", "incompleta", resultado de "mau gosto" do editor (TEYSSIER, 1982; BOMFIM, 2008), saindo-se que diante da incerteza a sombreá-la cautela faz-se necessária em sua análise, por isso algumas palavras sobre a edição selecionada precisam ser ditas.

Explana-se, "por motivos operacionais", como fizera Bomfim (2008, p. 12), ao detalhar o texto de que se serviu das obras do dramaturgo, que a edição a ser utilizada das Obras de Gil Vicente, contando com seus Autos, Farsas, Comédias, Tragicomédias e textos de natureza diversa (sermão, trova, paráfrase, epístola etc.), data de 1965, publicada pela casa portuguesa Lello \& Irmãos, a qual derivou da pertencente ao livreiro francês Ernst Chardron, que emigrou para Portugal em 1865. A editora foi vendida aos irmãos José Pinto de Sousa e António Lello em 1894 (SALLA, 2016), e ainda está em plena atividade há mais de um século, no habitual endereço - Rua das Carmelitas, 144, Porto.

Defende-se que se trata de fonte de pesquisa que goza de confiabilidade dada a experiência em edição e publicação de livros que a Lello \& Irmão possui e o próprio passado remetendo a Chardron, o primeiro editor de Eça de Queiroz, ao qual deram continuidade, aprimorando as estratégias de divulgação para vendas e mantendo a profissionalização dos trabalhos. Chardron era editor respeitado com mais de 1500 obras publicadas e vendidas em Portugal e além-mar, e prezava pela qualidade das publicações (OLIVEIRA JÚNIOR, 2016).

Destarte, crê-se ter à disposição exemplar fiável das obras vicentinas com o auxílio do qual há de se passar para o terceiro momento desta produção, momento de leitura e análise em busca de vestígios, de rastros daquelas questões, inquietações e problemas levantados pelos filósofos do medievo deixados consciente ou inconscientemente nas linhas, falas de seus personagens, atendo-se esta análise mais especificamente aos autos do período que se estende de sua primeira peça encenada, o Auto da visitação (1502), ao último que compõe esse grupo de escritos, o Auto da festa (1535). 


\section{Os autos vicentinos contêm problemas filosóficos?}

Por que um autor de teatro da Renascença ${ }^{14}$ ocupar-se-ia tanto de assuntos medievais? Seria uma característica de sua obra? E seria esse "resgate" uma opção, quer dizer, uma tomada de posição lúcida do escritor à maneira de crítica, como sói ao teatro ${ }^{15}$, de um passado próximo, ou, na verdade, não seria um patente reconhecimento de que Gil Vicente, apesar de estar no limiar da modernidade, era homem do medievo? Acaso pesaram-lhe mais as indagações do homem deste momento que as em efervescência, resultantes de nova época cujo início pôde testemunhar? Esses são alguns questionamentos postos como diretrizes para que se leve a cabo o exercício de investigação e comentário que se propôs.

Tentativa de esclarecimento das inquirições feitas no parágrafo anterior consta nos trabalhos do professor José Augusto Cardoso Bernardes (2004-2005, p. 194) e de Silvia Cristina da Silva Coelho (2017), para os quais arrancar Vicente da "medievalidade a que definitivamente pertence" e querê-lo renascentista e, consequentemente, humanista é apagar o ethos que lhe serve de base de compreensão do mundo e da sociedade da qual é filho, e negar a tradição literária na qual se inscreve e que há de lhe definir como teatrólogo.

Se por um lado autores como Aragão (2002) reconhecem no texto vicentino, como este o faz ao analisar o Auto da Alma, a menção ao platonismo disfarçado de doutrina agostiniana, descrevendo a estrutura da alma como pensada pelo bispo de Hipona, certa referência filosófica, portanto, saltando de sua escrita, por outro, faça-se saber que menções afins a temas filosóficos têm sido mal exploradas, detendo-se no óbvio caminho platônicoaristotélico, agostiniano-tomista, por isso limitando-se a deduções não difíceis de serem tiradas por quem toma par do assunto. A fim de avançar no tópico, propõe-se, a seguir, os trechos e os temas filosóficos medievais aos quais estariam relacionados para que melhor se perceba a influência deles na escrita vicentina.

Certo da salvação proclamada pela moral cristã, a partir do desapego e abandono das coisas deste mundo, estendendo-se essa visão à filosofia, no Auto de S. Martinho (1504), encontra-se a expressão desse desapego e a não temeridade da morte, a morte é libertação, destaque na primeira estrofe, porque esta guarda o caminho para o encontro com a divindade, cuja existência tornou-se problema para os filósofos da Idade Média, e o cumprimento das promessas feitas, na fala inicial do Pobre (VICENTE, 1965, p. 46, negritos meus):

Dejadme pasar por esta carrera,

Ire á buscar un pan que sostenga

Mi cuerpo doliente, hasta que venga

La muerte que quiero por mi compañera.

\footnotetext{
${ }^{14} \mathrm{Na}$ página 3, acima, há comentário de Alain de Libera (2011), o qual se aplica às delimitações impostas para outros períodos da história. Via de regra, por Renascença entende-se, no Ocidente cristão, o recorte espaço-temporal compreendido entre os séculos XV a XVI, com alguma variação para trás e para frente consoante o ponto de referência que se tenha. Para o historiador norte-americano Will Durant (c. 1953), o Renascimento se estende do ano do nascimento de Petrarca (1304) ao ano da morte de Ticiano (1576). Saraiva e Lopes (2010) em seu livro, localizam Gil Vicente no capítulo intitulado " 3 a Época - Renascimento e Maneirismo", donde se retira compreensão de estar o dramaturgo inserido cronologicamente, ao menos, nesse momento da história europeia.

15 "Há uma arte que, pela sua natureza, ao se concentrar nas tensões e contradições entre indivíduos e sociedade, absorve os maiores conflitos do ser humano em busca de felicidade entre as contingências da realidade. Esta arte é o teatro, ou se preferível os teatros, o qual através da escolha entre várias linguagens e estilos move-se nos palcos e em outros espaços em um diálogo constante com a vida política, social e cultural de um país” (TABARES, 2011, p. 161, itálico da autora).
} 
Mirad ora el triste que estoy lastimado

De pies y de manos por mi desventura;

Mirad estas plagas que no sufren cura;

Ya son incurables por mi triste suerte.

Ay! que padezco dolores de muerte

$\mathrm{Y}$ aquesto que vivo es contra natura.

Haved compasión del pobre doliente,

Que ya se vió mancebo y lucido.

Ó mundo que ruedas, á qué me has traído!

Qué rezio solia yo ser y valiente.

Cuán alabado de toda la gente!

De rezio, galan, qué fue de mi bien?

O muerte, qué tardas, quien de detien;

Que yo no me atrevo á ser mas paciente!

A personagem ao mesmo tempo em que lamenta seu estado, possivelmente, a desobediência às leis divinas trouxe-lhe infortúnios, destaque na segunda estrofe, reconhece que em razão de haver incorrido em faltas morais, ou na prática do menor dos males, já gozara dos bens desta vida, destaque no trecho final.

Ao personalizar vícios, virtudes e figuras comumente representadas desde a filosofia grega como a alma (psukhe), à qual dedica um auto, a sorte, às vezes como glória dos heróis, a kléos grega, ou má sorte, a fortuna, o amor, que é paixão (pathos, sofrimento), por exemplo, Gil Vicente toca no problema dos universais porque lida com compreensões de época sobre esses conceitos, aventurando-se inclusive em problematizar seus significados ou, como se expôs na seção dedicada ao tópico, sua associação com aquilo que representam, como se percebe não apenas na fala do Frade, no Auto das fadas (1512): "Porque son palabras de tanto misterio, / Que ciega ó alumbra la humana razon" (VICENTE, 1965, p. 179). A mesma razão que empreende esforço considerável para descobrir o que seriam esses universais afinal, mas sempre lidando com limitações de entendimento que, por vezes, não a permitem ir além.

O problema do ser no mundo, questão metafísica, por isso ontológica, por excelência, pode ser vislumbrado em todos os autos vicentinos que lidam mais detidamente com a condição humana, com os fatos que marcam o existir do homem na terra, abarcando grande parte deles, aliado às questões referentes à moralidade, uma vida correta guarda recompensas, uma vida de pecados guarda punição, pois o homem medieval, isso a filosofia de certo o mostrou, caminha na linha tênue de sua existência, receoso de errar (pecar) e atento para que suas ações o aproximem de Deus, por isso se queixa o Fildago no Auto da barca do inferno (1517):

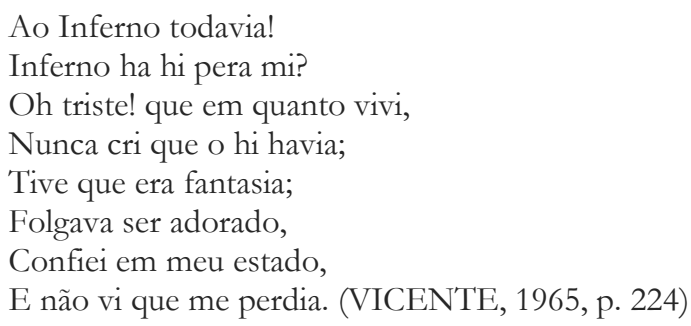

E por isso reflete Job no Auto da história de Deus (1527) sobre a natureza do bem e do mal, questionamento de fundo metafísico e expressão visível da moralidade filosófica 
medieval, quando são pesadas as consequências das ações do homem e da mesma forma discutida a questão do livre-arbítrio e do determinismo:

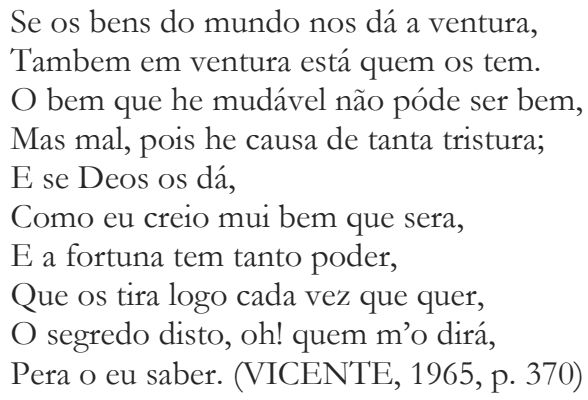

Ainda sobre o mesmo auto, não se crê haver peça mais expressiva de problema da filosofia do medievo que o Auto da história de Deus (1527), pois desde o título nota-se que se Gil Vicente pretende narrar em verso a história desta divindade, é porque, como homem do medievo, a partir do caminho comum por meio do qual a filosofia tratou da questão à época, acredita em sua existência e em suas qualidades tão louvadas pelas autoridades da filosofia medieval, ser onipresente, onipotente e onisciente, criador que cria do nada, feito do qual se admira o próprio Lúcifer ao declarar:

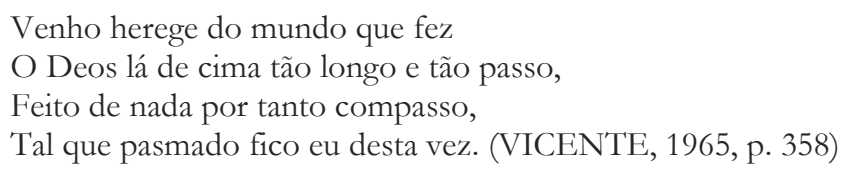

Fechando com esse trecho, por fim, pode-se compreender que, imerso em sua época, mas respirando aquele forte ar do medievo, Gil Vicente constituiu sua obra teatral dedicando nela bastante espaço para o trato ou a apresentação dos problemas da filosofia desse tempo que foi a Idade Média.

Se forem as buscas aprofundadas e o olhar se detiver mais - aqui se pretendeu tão somente demonstrar que havia nas linhas vicentinas, expostos e não apenas subentendidos, problemas, questões e inquietações da filosofia do medievo - possivelmente mais vestígios hão de ser encontrados, reafirmando que o teatro vicentino é mais que apenas medieval, é filosófico.

\section{Considerações finais}

Quem se empenha em tecer comentários à maneira de balanço da filosofia do medievo - e da cultura da Idade Média, em espectro mais amplo - cujas investigações centraram-se, inicialmente, no comentário dos autores gregos - em especial Platão e Aristóteles, mas também Plotino (século III EC) e Agostinho (século IV EC) - passando ao problema dos universais e avançando para temáticas metafísicas como o bem $/ \mathrm{mal}$, o livre-arbítrio, atravessadas pela tentativa de se conciliar fé e razão, deve ter em mente tudo o que ela real ou figurativamente representa para a cultura ocidental e cautela para não reproduzir lugarescomuns e equívocos persistentes em afirmações deficientes ou leituras desavisadas, ainda mais quando se recorre a fontes de natureza duvidosa, contrariando as "reconhecidamente aceitas", o que, certamente, se buscou evitar.

Cada um dos momentos e das tradições filosóficas que contribuíram para a formação 
e consolidação do pensar daquela época partiu de um eixo comum, a filosofia grega, e o ampliou a partir de suas referências culturais e visões de mundo. Destarte, produziu-se uma filosofia cujos raios iluminam com fulgor variado o céu dos contemporâneos, pois mesmo hoje a filosofia está a discutir ou em busca de esclarecimentos para aquelas querelas incitadas pelos medievais, tão profundas e genuínas que foram e por cuidarem de inquietações ainda pulsantes no âmago do homem deste século, o XXI.

Precioso achado é o da presença das questões filosóficas acima explicitadas nas linhas dos autos vicentinos trazidos para discussão; o que permite concluir não apenas ser abrangente o cabedal cultural do dramaturgo de Portugal, como a importância que este deu a certos elementos da filosofia medieval, transportando-os para sua obra aqui e ali como crítico da sociedade quinhentista em que viveu.

Se as constatações apresentadas se repetissem indiscriminadamente, poder-se-ia deduzir que Gil Vicente, à maneira de alguns filósofos do medievo, não passava de um repetidor de conteúdos e motivos, mas pelo exposto, enxerga-se personagem histórica atenta às vicissitudes, aos questionamentos e às fragilidades de seu século, disposto a registrar para o olhar dos pósteros e além aquilo que lhe aprazou ou incomodou.

Cabe a este escrito servir de registro e testemunho para cá e alhures, para o presente e para o porvir de um esforço empreendido a fim de se poder trazer novidade sobre autor bem discutido, compondo o cânone da literatura medieval e ocidental, bem como grande nome do teatro, e cuja obra tem sido motivo de estudo e análise.

\section{Referências}

ARAGÃO, Ludumila. Auto da alma: uma alegoria tardo-medieval? Revista da Faculdade de Letras “Línguas e Literaturas”, Porto, XIX, 2002. pp. 235-246.

BEN-SHAMMAI, Haggai. Kalam in medieval Jewish philosophy. In: FRANK, Daniel H.; LEAMAN, Oliver (Eds.). History of Jewish philosophy. New York: Routledge,1997. p. 91-117. BERNARDES, José Augusto Cardoso. A Compilaçam de Todalas Obras: o livro e o projecto identitário de Gil Vicente. Diacrítica, Ciências da Literatura, n. 18-19/3, 2004-2005, p. 179198.

BOMFIM, Eneida. O traje e a aparência nos autos de Gil Vicente. Rio de Janeiro: Ed. Puc-Rio, 2008.

COELHO, Silvia Cristina da Silva. A presença da sublimitas in bumilitate em três autos de Gil Vicente. Dissertação (Mestrado em Estudos Literários) - Universidade Federal de Minas Gerais, Faculdade de Letras, UFMG, 2017.

CORBIN, Henry. Histoire de la philosophie islamique. Paris: Gallimard, 1986.

DOUGHERTY, Michael V. Moral dilemmas in medieval thought. from Gratian to Aquinas. New York: Cambridge University Press, 2011.

DUIGNAN, Brian (Ed.). Medieval philosophy: from 500 to 1500 CE. New York: Britannica Educational Publishing / Rosen Educational Services, 2011.

DURANT, Will. A renascença. 2. ed. Rio de Janeiro: Editora Record, c. 1953.

ERIC, Osborn. The beginning of Christian philosophy. New York, Cambridge University Press, 1981.

EYLER, Flávia Maria Schlee. Linguagem e poder no teatro de Gil Vicente. Caderno do IL, Porto Alegre, n. 49, dezembro, 2014. pp. 159-175.

GIGANTES DA LITERATURA UNIVERSAL. Gil Vicente. Lisboa: Editora Verbo, 1972. 
GILSON, Etienne. A filosofia na Idade Média. São Paulo: Martins Fontes, 2001.

GUTTMANN, Julius. Philosophies of Judaism: the history of Jewish philosophy from biblical times to Franz Rosenzweig. New York: Anchor Books, 1966.

JOSPE, Raphael. Jewish philosophy in the middle ages. Boston: Academic Studies Press, 2009.

LIBERA, Alain. La querelle des Universaux: de Platon à la fin du Moyen Age. Paris : Éditions du Seuil, 1996. - La philosophie médiévale. Paris: PUF, 2001. - A filosofia medieval. São Paulo: Edições Loyola, 2011.

MARENBON, John (Ed.). The oxford handbook of medieval philosophy. New York: Oxford University Press, 2012.

MOISÉS, Massaud. A literatura portuguesa. São Paulo: Cultrix, 2008.

MOURA, Gilberto (Ed.). Teatro de Gil Vicente. 2. ed. Lisboa: Ulisseia, 1987.

MUNIZ, Márcio Ricardo Coelho. De Castela ... casamento: festa e política no teatro de Gil Vicente. In: BRADENBERGER, Tobias; THORAU, Henry (Org.). Portugal und Spanien: Probleme (k) einer Beziehung (Portugal e Espanha: Encontros e Desencontros. 1ed.Frankfurt: PeterLang, 2005, v. 45, p. 79-91.

NASR, Seyyed Hossein. Islamic philosophy from its origins to the present: philosophy in the land of prophecy. New York: State University of New York Press, 2006.

OLIVEIRA JÚNIOR, Virgílio Coelho de. Eça de Queiroz editor: representações sobre leitores, leituras e práticas de publicação, à luz dos diálogos epistolares e das narrativas romanescas (1877-1900). Fênix - Revista de História e Estudos Culturais. Vol. 13, Ano XIII, nº 1, janeiro - junho de 2016. p. 1-22.

PICCHIO, Luciana Stegagno. História do teatro português. Lisboa: Portugália, 1969.

SALLA, Thiago Mio. Ecos da Belle Époque Brasileira em Portugal: a recepção de Coelho Neto em terras portuguesas. In: XV Encontro ABRALIC, 19 a 23 de setembro, Rio de Janeiro. Anais do XV encontro ABRALIC, 2016. p. 1120-1131.

SARAIVA, António José; LOPES, Óscar. História da literatura portuguesa. 17. ed. corrigida e actualizada. Porto: Porto Editora, 2010.

TABARES, Vivian Martínez. Theater in revolution (1959-2010). Estudos Avançados 25 (72), 2011. p. 161-179.

TEYSSIER, Paul. Gil Vicente - o autor e a obra. Lisboa: Instituto de Cultura e Língua Portuguesa, 1982.

TRIGO, Salvato. Gil Vicente e a teatralização das linguagens. Comunicação, Semana de Estudos Portugueses, Departamento de Estudos Espanhóis e Portugueses, Universidade de Toronto, 1983. pp. 209-225.

VICENTE, Gil. Obras de Gil Vicente. Porto: Lello \& Irmão - Editores, 1965. 